\title{
'When you welcome students without borders, you need a mentality without borders' internationalisation of higher education: evidence from Portugal
}

\section{Cosmin I. Nada \& Helena C. Araújo}

To cite this article: Cosmin I. Nada \& Helena C. Araújo (2019) 'When you welcome students without borders, you need a mentality without borders' internationalisation of higher education: evidence from Portugal, Studies in Higher Education, 44:9, 1591-1604, DOI:

10.1080/03075079.2018.1458219

To link to this article: https://doi.org/10.1080/03075079.2018.1458219

\section{Published online: 04 Apr 2018.}

\section{Submit your article to this journal $\pi$}

Џlll Article views: 705

Q View related articles ¿

View Crossmark data $[7$

Citing articles: 2 View citing articles 


\title{
'When you welcome students without borders, you need a mentality without borders' internationalisation of higher education: evidence from Portugal
}

\author{
Cosmin I. Nada (iD) and Helena C. Araújo (10)
}

Centre for Research and Intervention in Education (CIIE), Faculty of Psychology and Education Sciences, University of Porto, Porto, Portugal

\begin{abstract}
Compared to other major players in the global market of international education, internationalisation of higher education has only recently become a relevant topic in Portugal. In line with the worldwide increase of international students, Portuguese universities are also experiencing a growing in-flow of students willing to obtain a foreign tertiary degree. Anchored in international students' perceptions, this paper aims to understand how Portuguese universities deal with the increased diversity of their student bodies. The data result from an in-depth qualitative approach guided by the methodological assumptions of narrative inquiry and are analysed in the light of theories of multiculturalism. The findings give an account of numerous weaknesses in the way Portuguese universities tackle diversity, suggesting that institutional structures may reinforce assimilationist and deficit views of international students. Finally, considering that universities from other 'catch-up' countries may be confronted with similar issues, some empirically based recommendations are offered.
\end{abstract}

\section{KEYWORDS}

Internationalisation; higher education; multiculturalism; international students; Portugal

\section{Introductory and contextual notes}

In a global context marked by increased mobility and migration, higher education institutions from all continents are welcoming unprecedented numbers of international students. Although travelling abroad for studies is not a new phenomenon (Altbach 2004), levels of student migration have gained extraordinary proportions in the past decades. For instance, between 2000 and 2008, the number of international students worldwide increased by 70\% (Beine, Noël, and Ragot 2014), and reached an all-time high in 2013, when 4.1 million international students were recorded (Heng 2017). In line with this global tendency, Portuguese universities have also been receiving more international students, especially in the last two decades. Between 2001 and 2011 the number of international students enrolled in a higher education degree in Portugal almost doubled (from 11,821 to 21,702$)$, but appears to have stabilised in the following years $(20,573$ students in $2013,21,536$ in 2014, and 21,276 in $2015^{1}$ ).

These historically unparalleled numbers contribute to the significant cultural diversification of campuses, posing extra challenges to higher education institutions. In many countries, universities are struggling to find a balance between the pressures to generate more income through international fee-paying students, rooted in a market-oriented view of higher education (Urbanovič, Wilkins, and Huisman 2016), and the importance of supporting international students' transition 
and integration (Guo and Guo 2017), through the development of institutional strategies capable of assisting them in their academic quests. The effects of this increase in the numbers of international students have been widely documented in countries which are well-established in terms of international education, such as: USA (Lee and Rice 2007); UK (Montgomery and McDowell 2009); and Australia (Volet and Ang 2012). However, research on international students in smaller non-Englishspeaking countries is rather limited (some exceptions: Urbanovič, Wilkins, and Huisman 2016; Nada and Araújo 2017; Nada, Montgomery, and Araújo 2018).

Even though most international students enrol in universities from English-speaking countries (Barnett et al. 2016), many are becoming increasingly interested in non-traditional destinations (Rienties et al. 2012). Considering that contextual and historical aspects render each country unique, and '[...] can impact upon the recruitment and hosting of international students differently' (Urbanovič, Wilkins, and Huisman 2016, 504), the scarcity of research about universities from non-English-speaking countries constitutes a significant knowledge gap. Consequently, this paper seeks to provide a more contextual understanding of the relationship between international students and their host institutions, by analysing students' perceptions of the support provided by higher education institutions from Portugal, a 'catching-up' country in terms of higher education internationalisation (Horta 2010). In this sense, the term 'catch-up' country is used to describe the higher education sector of a non-English-speaking European country which started to develop 'comprehensive internationalisation strategies' as recommended by the EU (Deca, Egron-Polak, and Fiț 2015, 128), and which already has an internationalisation strategy 'in place' (European University Association 2013). However, 'catch-up' countries are not major players of the international education market (Urbanovič, Wilkins, and Huisman 2016) and '[...] are only beginning to get their feet wet in this area', as opposed to '[...] countries like the United Kingdom, Germany, France, and the Nordic countries [which] are among the trendsetters in internationalisation in Europe and beyond' (Rumbley, Altbach, and Reisberg 2012, 16).

In light of international students' perceptions, this paper seeks to provide a description of the manner in which Portuguese universities appear to be dealing with their increasingly diverse student bodies. The paper is structured in four different sections: the first two dedicated to the theoretical and methodological frameworks of the research; the third to the lived experiences of 12 international students in Portugal; and the fourth to the identification of empirically based recommendations directed to higher education institutions.

\section{International students and host universities: a multicultural perspective}

International students, along with other types of migrants, face many difficulties in their receiving countries. Challenges specific to the experience of migration include: 'culture shock, language difficulties, adjustment to unfamiliar social norms, eating habits, customs and values' (Toyokawa and Toyokawa 2002, 363). Additional challenges are posed by xenophobia, and the rising tendency of local residents to blame migrants for problems which exist in their societies. Contrary to the ideals of multiculturalism, dominant political discourses across the globe see '[...] migration as a problem that needs to be "fixed" by appropriate policies' (Castles 2010, 1567). Currently, these tendencies have been spreading and, in many developed countries, an increased support for populist, extreme-right wing political parties has been registered (Rooduijn 2015).

Perceptions of migration as something problematic are thus widespread. Similarly, international students are often seen by their universities as problems in need of solutions, given that diversity can be perceived as disturbing to the regular institutional functioning (Otten 2003). Since many institutions consider that international students require more attention than their local counterparts, many researchers have been predominantly focusing on this student group in terms of needs and difficulties. According to Lillyman and Bennett (2014), current literature tends to be negative in regard to international students' experiences, reproducing a 'deficit view' (Carroll and Ryan 2007) or a 'deficit model' (Montgomery and McDowell 2009). This problem-oriented view observed 
among higher education institutions and researchers alike, and the way in which higher education institutions position themselves towards international students and cultural diversity can be understood through the ideas expressed by multiculturalism.

Frequently theorised in the last decades and broadly used in social science research, multiculturalism has become a multi-layered and highly controversial concept. Since '[...] its semantic capital, as it were, has been spent' (Levey 2012, 223), it is important to clarify the meaning that this term assumes throughout the paper. Firstly, multiculturalism refers to a demographic feature of society, more precisely to '[...] the coexistence of a range of different cultural experiences within a group or society' (Bolaffi 2003, 83). However, the notion of multiculturalism, both in the political field and in academia, goes beyond this basic demographic meaning. For Castles (1997), multiculturalism appeared in the 1970s as a model for responding to requests from the increasing immigrant population. The initial multiculturalism 'melting pot' logic was substituted by metaphors such as 'salad bowl' or 'glorious mosaic' (Glazer 1998), suggesting that immigrants do not need to erase their previous characteristics in order to be able to join the new society. Indeed, the metaphors of the salad or the mosaic are frequently used in order to stress the importance of maintaining cultural and identity traits in a different group or society (Ferdman 2017). Along with the shift from an assimilationist view to a more inclusive paradigm and ambitions for a more democratic world, social demands by immigrants as well as ethnic and other minorities began to bloom. The concept of multiculturalism was thus placed in the political arena, where it gained a new meaning. According to Inglis (1996), the meaning of multiculturalism encompasses at least three different matters: 'the demographic-descriptive, the ideological-normative and the programmatic-political' (16).

According to Nye (2007), multiculturalism appears as an ideology or social programme which it is possible to be 'for' or 'against'. However, in view of the cultural diversity of the world, it can be argued that multiculturalism should not be framed as an ideology, but rather that it constitutes a basic condition for functioning societies. As observed by Walter (2018), multiculturalism seems to have become the 'new normal' in many educational institutions and, in Arasaratnam's view (2013), 'there is consensus that multiculturalism is an ideology as well as a pragmatic imperative' (683). Regarding its goals, Tiryakian (2003) sees multiculturalism as '[...] a normative critique of the institutional arrangements of the public sphere that are seen as injuring or depriving a cultural minority of its rights' (24). Indeed, the ability to denunciate and reduce inequalities rooted in non-dominant cultural traits may be considered as the main legacy of multiculturalism. In this paper, the concept of multiculturalism is applied to the context of higher education following the meaning described by Tiryakian. More specifically, multiculturalism appears here as a means to question if higher education institutions are being successful at ensuring the personal and academic rights of international students and their subsequent integration. In Tiryakian's (2003) words, are universities able to '[...] incorporate various minorities in the institutional fabric' (21); or are they reproducing institutional mechanisms of discrimination and exclusion instead?

With respect to international students, several parallels can be drawn between multiculturalism and higher education institutions. A significant increase in the numbers of students who go abroad has been registered since the '70s (Méango 2014), and universities cannot continue to ignore the resulting cultural diversification of their campuses. As noticed by Papastergiadis (2000), 'difference is no longer to be seen as something that is "out there" or "back then", because it is already part of the "here and now"' (94). Consequently, higher education institutions need to address cultural diversity as a fact, rather than as an eventuality or a marginal phenomenon. In fact, historically international education lies at the base of the formation of universities as such. According to Lee and Rice (2007), 'cross-border education has existed since the earliest formations of higher education, beginning with the University of Paris opening its doors to scholars outside France to train its students in the 13th century' (383). Nowadays, the internationalised university has ethnic and cultural diversity embedded in its student body, which does not reflect solely the global flows of international students but also increased domestic multiculturalism (Caruana 2014) and 'intranational diversity' (Dunne 2013). Taking into account the cultural diversity that characterises 
most higher education institutions in the world, multiculturalism - in its demographic meaning - is part of the daily reality of universities.

It is clear that 'globalisation cannot be completely avoided', while history has demonstrated that '[...] when universities shut themselves off from economic and societal trends they become moribund and irrelevant' (Altbach 2004, 6). Nevertheless, international students are often approached through a problem-centred perspective, and numerous universities are failing to promote multiculturalism at an institutional level. In some universities, international students are even '[...] differentiated as "special needs" or "non-traditional" students, with an assumed range of difficulties to be addressed' (Hughes and Bruce 2013, 107).

To move beyond such limited and limiting perspectives, it can be argued that both universities and researchers abandon the 'blame-the-student theory' (Biggs and Tang 2007, 17), replacing it with a more inclusive approach to international students' experiences. Even though 'different' does not necessarily equal 'deficient' (Heng 2017), anecdotal perceptions of international students as deficient in language and study skills are quite widespread (Montgomery and McDowell 2009). In fact, most research on international students seems to be captive within '[...] a problem framework that presents them as having a set of identifiable and correctable problems rather than focusing on any inadequacies within the host community' (Lee and Rice 2007, 388). In multicultural terms, such perspectives are rooted in assimilationist assumptions, since they presume that international students are the ones who need to adapt, while host universities can simply remain unchanged.

In other words, the old multiculturalism logic of the 'melting pot' (Glazer 1998), seems to persist in contemporary universities. A fundamental condition for an institutional switch from assimilationist stances to a multicultural perspective is stopping to regard '[...] difference as a deficit' (Asmar 2005, 291), and to instead address diversity as an educational resource (Dunne 2013). Asmar (2005) also warns that diversification of student demographics poses new and complex challenges to teaching and learning practices. At the same time, if universities actively seek to implement multiculturalism on their campuses, the positive effects of cultural diversity can overshadow the challenges faced both by teachers and students. According to Shaw (2009), student diversity has been empirically associated with academic benefits for all students, since a multicultural campus can provide a fruitful ground for cultural understanding and tolerance towards diversity (Volet and Ang 2012).

In spite of the potential benefits of cultural diversity, Papastergiadis (2000) notes that multiculturalism does not occur spontaneously, nor are the opportunities offered by diversity in educational contexts automatically available (Otten 2003). Thus, to transcend assimilationist approaches, higher education institutions need to change the way in which they address international students' experiences. According to Lee and Rice (2007), 'previous research has documented the tremendous difficulties that international students encounter but frequently fails to critically examine the underlying reasons as to why international students struggle in their host environment' (404). While a significant amount of research has already analysed international students' difficulties and struggles, the focus of this study will therefore lie upon students' perceptions of being (un)welcomed to their host countries and universities. A main objective is to draw on the experiences of international students to identify empirically based recommendations capable of providing higher education institutions with relevant insights on how to better integrate and support culturally diversified students.

\section{Methods}

This paper draws its empirical basis from a narrative inquiry focused on the experiences of twelve international students in Portugal. The process of participant selection was informed by a 'purposeful sampling' technique, based on the principle of maximum variation (Koerber and McMichael 2008). Maximum variation was preferred to other sampling techniques since we wanted to understand international students' experiences in their complexity and diversity, illuminating several different facets of their international sojourns. The use of this technique resulted in a highly diverse participant 
set (different nationalities, geographic origins, ethnicities, mother-tongues, faculties, and studycycles). In addition, each three students were enrolled in a different Portuguese university, selected in accordance with its geographic position, number of international students and total number of students. The selection of four distinct universities was guided by the intention to address students' perceptions regarding institutional support mechanisms in the most prominent universities in Portugal, and from different regions of the country. Moreover, it is noteworthy to emphasise that research participants were not exchange students - as, for instance, Erasmus - but international students enrolled in a full higher education degree in Portugal (Bachelor's, Master's or PhD). Before participating in this research, all students were asked to sign an informed consent and their anonymity was ensured through the use of fictitious names.

Although '[...] the term "narrative inquiry" is gaining precedence in the literature' (Trahar 2008, 260), there is hardly any consensus regarding the specific characteristics of this form of inquiry. As observed by Spector-Mersel (2010), 'reading through the narrative literature, diversity appears to be the name of the game' (205). Within such a diverse panoply of perspectives on narrative inquiry, it is crucial to provide a working definition and to describe, in line with Etherington (2004), what narrative means to us in this context, and which were the ontological and epistemological assumptions that guided the research.

In this sense, it is also important to underline the autobiographical character of this study, acknowledging that its leading researcher is a former international student in Portugal. Considering that '[...] narrative inquiry is necessarily autobiographical' (Saleh, Menon, and Jean Clandinin 2014, 272), this research emerged from a first-hand experience of studying in a Portuguese higher education institution and is motivated by the ambition to understand in a more systematic way, how international students cope with the experience of living and studying in a foreign country. The decision of exploring narratively the experience of international students in Portugal was influenced by the fact that experiences in international contexts are ' $[. .$.$] difficult to describe, interpret, and con-$ ceptualize' (Erichsen 2011, 111). Therefore, instead of simply asking questions through a more traditional process of interviewing, we assumed that thoughts on participants' experiences as international students in Portugal might not be readily available in their minds. Students might find it difficult to provide insights about aspects that they might never have reflected upon. Our methodological choice was guided precisely by the intention to give participants the opportunity to reflect upon their own trajectories, and reach new understandings of their experiences in Portuguese higher education. Hence, we opted for narrative inquiry, since it allows researchers to 'get at information that people do not consciously know about themselves' (Duff and Bell 2002, 209). Rather than merely collecting data, we felt the need to stimulate students' reflexivity and to construct meaning through our interaction.

In regard to the actual modus operandi of this narrative inquiry, each student was asked, in a first interview, to recount his/her experience as an international student in Portugal. In these interviews, students were not asked specific questions but were only requested to recount their lives from the moment in which they decided to nurture the idea of going abroad, allowing narratives '[...] to emerge of their own accord' (Yuen 2008, 297). This first interview was then transcribed and, instead of sending the transcripts to students, they were invited for a second interview in which the text was read and discussed in-depth: the researcher would read each paragraph aloud, pause, and ask students to add new information, clarify particular aspects of their stories and reflect upon the meanings of their own experiences as international students in Portugal. This strategy was rooted in the assumption that 'if story-givers are to make sense of and provide coherence to their lives, they must have sufficient opportunity to read, reflect upon, and find meaning in their stories' (Larson 1997, 467). Albeit rather time-consuming, the strategy proved to be empirically productive. In some cases, the process was so extensive that five interviews were necessary before completing the narrative of one student. All in all, 41 biographic interviews were conducted with an average duration of two hours each, totalising 78 hours of audio recordings and resulting in 12 narratives of international students in Portugal. In contrast to the traditional process of data collection, 
the 12 research participants were involved in the actual co-construction of the data (Riessman 2005). Participants' experiences resonated with the researcher's, at the time an international student himself, and that provided the grounds for a fruitful interpretive work conducted jointly by participants and the researcher.

Students' narratives were then subjected to a thematic narrative analysis (Riessman 2005) focused on students' perceptions over the welcoming strategies employed by their host universities. Given that the way in which higher education institutions deal with the increased diversity of their student bodies is addressed exclusively through students' narratives and own perspectives, it lies beyond the scope of this paper to produce findings generalisable to other student populations or institutions. Instead, its aim is to challenge existing generalisations about international students, in line with Ploner's (2015) approach, and to generalise towards theory rather than towards populations (Bryman 2012).

\section{Students' experiences of being (un)welcomed to the host university}

The research literature recognises the numerous and diverse struggles that international students tend to experience during their international sojourns. For instance, Avery (2016) argues that: 'gaining the social and cultural capital needed to succeed in a new country with a new language and unfamiliar education system is a slow and complex process' (2). Similarly, Brown and Graham (2009) observe that international students experience increased difficulties particularly in the beginning of their sojourns, when they need to deal with new academic and sociocultural environments. For these reasons, many students rely on institutional support mechanisms in order to be able to successfully navigate their new socio-academic environments. In this study, students' perceptions of the institutional support mechanisms made available by Portuguese higher education institutions are rather unsatisfactory. Across the participant set, international students pointed out failures in the strategies employed by Portuguese universities to address cultural diversity. For instance, Naim, a male Master's student from Turkey, mentioned the existence of loose requirements for university admission, a factor capable of negatively influencing international students' academic experiences.

Somebody applies for the programme, they accept that person but they don't know who it is, they accepted whom? This is a problem in Portugal, things are not very professional. (Naim)

In this excerpt, it is possible to note that Naim felt somehow disregarded by his university, even before actually starting his Master's. Based on his perception, according to which things are not very professional in Portugal, this student was concerned that the rapid university admission might subsequently translate into academic failure. For instance, allowing the enrolment of international students in programmes taught in Portuguese without testing student's linguistic abilities seems to be a questionable policy, which can lead to unpleasant situations, as noticed by Chang, a male Master's student from China:

I also had a teacher who, due to my difficulty in understanding the words, said: "With this level of Portuguese you cannot study in the Master's programme". I got upset and I wanted to ask her: "I paid tuition, if you think that I don't have the capability to be in this programme, why the director accepted me then?" (Chang)

In this case, there seems to be a gap between university enrolment goals and teachers' pedagogical struggles associated with teaching students whose first language is not Portuguese. This gap affects negatively not only teachers, who may feel unprepared and unable to support students who are not proficient in the language of instruction, but also students, since they have to struggle both with the difficulties inherent to studying in a different language and also with insufficient support from their teachers. Most worrying, the narratives indicate that none of the 12 students were asked to provide proof of their language skills in the university application form. Considering that the vast majority of programmes offered by Portuguese universities are taught in the local language, by allowing all international students to enrol in a tertiary degree, regardless of their Portuguese language knowledge, 
higher education institutions are passing to students the responsibility for their potential academic failure. A similar situation was narrated by Laina, a transgender PhD student from Laos, who was told, before arriving, that all classes would be administered in English. When she arrived in Portugal, the reality appeared to be quite different:

All the classes were conducted in Portuguese and I was so sad. I did not expect anything like that. I can say I was quite disappointed with the school system because I was told in the application that all classes will be conducted in English. (Laina)

Her narrative suggests that this situation significantly affected the educational outcomes of Laina's sojourn in Portugal. In fact, her experience as a whole was marked by a profound dissatisfaction with the Portuguese educational system, especially on account of the language struggles she experienced in classroom settings.

You go to one country and you don't speak the language, you don't know anything about it and then you have to attend the class which is spoken in that language. How is that possible? (Laina)

Amivi, a female Bachelor's student from East Timor, provides another example of a questionable institutional stance towards international students, marked by unacceptance of diverse ethnic and racial identities. In her narrative, Amivi recalls several episodes in which, according to her perception, teacher' attitudes towards international students were influenced by racial prejudices.

The teachers, in some disciplines, it seems to me that they are really racist. Two teachers in particular. (Amivi)

[The teacher during class, when we discuss practical examples in Law], she would not ask any dark-skinned person questions, she would mainly ask the white students ... the black ones, the darker ones, she wouldn't ask. [...] We were all [in class] and she asked a Portuguese, the student answered, then there was a Timorese, she passed on to a Portuguese [ignoring the Timorese], then there was another Timorese and, again, she passed on to a Portuguese. (Amivi)

Along with teachers' attitudes, Amivi also experienced many challenges in interacting with local peers:

Perhaps our colour is strange to them, I don't know, because students are very young also. [...] Because they saw this group of dark-skinned people among them, it might be strange to them. (Amivi)

Another episode of discrimination was brought up by Valéria, a female PhD student from Brazil. She considers that her teachers used to discriminate against Brazilian students, based on the assumption that the scientific production from their country was somehow inferior to European standards.

There was an academic shock: none of what was being done there [in Brazil] was valued here. [...] But I think this is specific to this $\mathrm{PhD}$ in particular, it is not something [that happens] in the whole university. [...] Therefore, inside academia, there is a certain resistance towards Brazilian students. For a very short time, I got to attend another $\mathrm{PhD}$ and there was this Nigerian who complained precisely about that: he felt discriminated against due to his origins. (Valéria)

Although she considers that these situations are not specific to the whole university but only to some PhD programmes, such behaviours should not exist among the teaching body of an internationalised university. In the excerpt below, Valéria warns that being a long-established university will not suffice and will not provide, by itself, an adequate institutional welcoming strategy directed to international students. She also stresses the importance of having an open mind when dealing with a culturally diverse student body.

[This] is a university that welcomes all races, in which you can see students from all over the world, thus that university needs to have teachers capable of exiting their own world. [...] Ok, it is true that the University of Coimbra is seven hundred years old, but there are universities which are forty years old and they are thirty years ahead of Coimbra. (Valéria)

In the excerpt below, Valéria also reiterates Chang's and Naim's complaints about the admission of international students, without guaranteeing that their learning needs can be met. To illustrate the 
inadequacy of the institutional strategy directed to international students perpetuated by her university, this student makes use of a metaphoric example:

It is like you were to receive a guest in your house and you would not care about knowing absolutely nothing about that guest. You will make dinner, you don't care if the person is carnivorous, vegetarian, you simply make what you like to eat, if the person wants, then he/she can eat. So what is going to happen? The person will arrive, will look at your food and will not eat, will leave [your house] hungry. Therefore, I think that the host has the obligation to know the reality of his/her guest and, when I come here, I am a guest. (Valéria)

This excerpt is particularly valuable for understanding the structural changes that universities need to implement in order to embrace diversity and become multicultural, not only in their composition but also in their daily practices. According to Valéria, it is not enough to merely admit overseas students, but universities need to be informed of the reality of those students. In this sense, universities should offer adequate training to prepare teachers to successfully deal with culturally diverse classrooms. Besides the inadequacies mentioned above, the narratives of some students suggest that their universities have not yet developed an institutional structure consistent with the recent increase in the number of international students in Portugal. For instance, Brenda, a female Master's student from the USA, noticed a complete absence of orientation activities directed to international students.

I just went to my first class and I thought it was strange that, as an international student, I never got anybody saying like: 'Would you like to go to an orientation or learn more about the university or talk to other international students?'. Nothing. So maybe they don't do that for Master's students or they don't do it at all. (Brenda)

Taking into account the hypothetical situation of having had the opportunity to receive some orientation, Brenda warns that there are certain limits to orientation activities, especially in regard to academic contents and language struggles:

I think if I had some orientation for international students it wouldn't make a difference in terms of the actual classes and the language. But there were a lot of little things that added up and made me frustrated as well, so some kind of orientation could have helped. (Brenda)

Similarly, Tânia, a female Master's student from Angola, points out the inexistence of a welcoming strategy for international students, underlining the fact that those who come from different countries should receive extra attention:

[There should be a] way to boost these students [academic] performance, to give them a different attention. It is not that we are different but, in fact, we came from a place with different characteristics, thus there should be a bigger attention, a different treatment. (Tânia)

Aiko, a female Bachelor's student from Japan, shares a similar perception, and underlines the lack of support specifically directed to international students. In the excerpt below, this student notices the existence of support mechanisms, though none appear to be suitable to her status.

At the university, there is no support for foreign students. Perhaps directed to Erasmus students, yes, but those are activities [specifically directed] to them. To me, no. The Chinese have an institute which belongs to the university and I think that they support Chinese students. Other students I don't know what they have but, for me, there is nothing. (Aiko)

Interestingly, according to Aiko's testimonial, being an international student does not necessarily guarantee access to institutional support mechanisms, given that most initiatives are directed to particular national groups or solely to students involved in exchange programmes. Not being an exchange nor a Chinese student, Aiko felt excluded from those activities, and the resolution of issues related to her integration remained in her own hands.

Along with their perceptions of the institutional support they have received during their sojourns in Portugal, students also referred to some episodes concerning teachers. For instance, Tânia complained about her teachers' inability to acknowledge and welcome diverse students to their classrooms: 
The teachers [...] limit themselves to giving the content they need to give, and they know they have foreign students in the class. I don't think that's right. There should be a greater attention, [...] especially from teachers towards students who come from overseas. (Tânia)

Unsatisfied with her relationship with teachers is also Aiko. According to this student, teachers were rather distant in relation to her, but not to other colleagues.

Sometimes I get the feeling that teachers [...] are not able to understand how I am. I felt some distance from them in comparison with other colleagues. (Aiko)

Another observation regarding teachers belongs to Valéria who considers that a diverse student body requires open-minded teachers, capable to see beyond the limits of their local reality:

When you welcome these students without borders, you need to have a mentality without borders. [...] What you notice here is that the majority of teachers ... they don't look ahead, they don't have a macro vision of the world, they live in their own universe. (Valéria)

In spite of these negative perceptions of teachers, some students also mentioned several positive experiences. In the excerpt below, Laina tells about the differential treatment she receives from her supervisor, who appears to be aware of this student's particular struggles, providing her extra attention.

She [my supervisor] is wonderful, she is in fact worried a lot about my research paper because she knows my condition, that I don't speak Portuguese, and she completely understands that I might have to work harder compared to other students, so that's why she pays more attention to me in regard to my education. (Laina)

Similarly, Brenda indicates that teachers were able to adapt to her academic needs and especially to her linguistic struggles. She emphasises that supporting international students does not necessarily imply simplifying academic content for them.

I felt support from most of the professors. Once they realised that I was there and wasn't a native speaker, most of them made an effort to, not simplify things for me, but to help me get a little closer to the level of the native speakers. (Brenda)

At the same time, Brenda warns that teachers' good intentions can have, in certain cases, the opposite effect: instead of aiding students in their adaptation, some support strategies could push them towards marginalisation and exclusion:

Sometimes, maybe you can feel like a burden, if you feel people have to explain things for you, to talk more slowly, or more simply. You don't always want people to single you out and make it clear that they are nice and helping [...]. Like that, it's being made even more clear that you're kind of different. (Brenda)

Even though some teachers seem to deal with their diverse students in an appropriate manner, several examples of less successful practices have been identified by the 12 participants. Furthermore, the lack of institutional support mechanisms was emphasised by all students and played an important role in their narratives. Hence, the existence of inadequate institutional strategies to tackle diversity does not seem to be specific only to one higher education institution, but appears to be shared by all four universities addressed in this research.

\section{Empirically based recommendations for multicultural universities}

Based on students' perceptions, most narratives revealed significant weaknesses in the strategies employed by Portuguese universities to deal with their increasingly diverse student bodies. In fact, some situations narrated by students raise doubts regarding the actual existence of an institutional strategy focused on diversity issues, and especially on international students. For instance, the research participants noticed:

- a certain institutional laxness in admitting international students to a particular degree programme without testing their language skills and without providing a structure capable of further ensuring their academic success; 
- a lack of orientation and support activities directed to international students;

- the existence of inadequate attitudes towards international students on behalf of teachers, such as failures in acknowledging the cultural diversity of their classrooms and the use of discriminatory behaviour rooted in prejudices related to the ethnicity of international students, or country of origin.

Certainly, such an institutional stance towards diversity can be prejudicial not only for the international students as individuals, but also for the universities themselves, especially in a world marked by intense competition in the international education market (Urbanovič, Wilkins, and Huisman 2016). As observed by Heng (2017), policy improvement is paramount if higher education institutions are to be successful at attracting international students. Against this background, it is worrying that the data gave an account of many failures in the Portuguese context, especially in regard to university admission requirements. For instance, negligent processes of selection seem to allow students with insufficient language skills to enrol in Portuguese-taught programmes. Even though most students know that classes will be taught in Portuguese, some may decide to enrol nevertheless due to unrealistic expectations with respect to the time required for acquiring sufficient language skills to cope with academic demands. This causes unnecessary difficulties not only for students, but also for their teachers who may feel obliged to find ad hoc solutions for these cases. A process of selection that takes into account the language skills of foreign candidates could certainly avoid such situations. The data also show that negligent processes of international student admission may lead to unacceptable situations of certain students who end up attending classes in Portuguese even though they were informed, prior to their arrival, that they would be attending English-taught courses.

Moreover, the narrative excerpts suggest that cultural diversity may not be readily acknowledged in some higher education institutions. After acknowledging the existence of cultural diversity, universities should also take into account that both international and local students have specific (learning) needs and requirements. At the same time, guaranteeing international students the same rights as local students is not enough, especially if their cultural specificities are not taken into account (Nada and Araújo 2017). Inadequate institutional practices for dealing with diversity, as the ones depicted above, may encourage the 'naturalisation of inequalities' (Casa-Nova 2013, 146) within the campus and, eventually, jeopardise the development of a satisfactory learning experience.

At the same time, it is important to consider that support mechanisms, such as orientation sessions or other types of institutionally organised activities directed to international students, do not constitute a panacea for their successful adaptation. As observed by one of the research participants, the struggles with academic content and the linguistic difficulties frequently experienced by international students cannot be successfully addressed through orientation alone. However, as stated by the same student, regardless of its limitations, initial orientation is still important for those students who live and study in a foreign context. Even though '[...] many universities provide orientation programmes for international students' (Caruana and Ploner 2010, 14), according to students' perceptions, that does not seem to be the case in the four Portuguese universities addressed in this research.

Students criticised teachers for being distant and, given that some appeared incapable of thinking beyond the confines of their own local reality, for not having a multicultural worldview. Some international students also considered that teachers were unaware of their particular struggles and needs, and therefore not able to provide adequate assistance. Indeed, previous research indicated that university staff does not always consider potential cultural difficulties experienced by international students, misinterpreting certain behaviours and thereby perpetuating students' problems (Lee and Rice 2007). Similarly, some teachers appeared to be 'suffering' from 'cultural daltonism' (Stoer and Cortesão 1999), failing to identify the cultural diversity present in their classrooms. The concept of cultural daltonism is applied to those teachers who are unable to see and to acknowledge the different colours of the 'sociocultural rainbow' (Cortesão 1998) which exists in their classrooms and, consequently, who do not take into account the need to develop and implement pedagogic approaches adapted to the specificity of each student. Therefore, some students criticised teachers for acting as if they did not have international students in the classroom, and for not employing 'culturally 
responsive pedagogies' (Heng 2017, 12). In line with previous research (Guo and Guo 2017), experiences of discrimination and racism were also mentioned by some of the students, who felt discriminated against due to their origin/skin colour. These findings suggest that campuses are not racismfree spaces, confirming that '[...] universities are still sites where whiteness can be reclaimed' (Cui and Kelly 2013, 172).

In spite of the negativity that marked students' accounts about the way in which they were welcomed by their teachers, several positive examples were also mentioned. For instance, one student noticed that teachers became more supporting once they acknowledged that she was not a native Portuguese speaker. This support did not involve reducing the level of academic exigency through content simplification. In fact, previous research demonstrated that simplifying academic content for students who are not fluent in the teaching language can have an inverse effect, negatively affecting learning outcomes (Callahan 2005). These observations suggest that Portuguese universities should invest in the identification of pedagogical good practices that already exist inside their institutions, encouraging teachers to reflect upon them, and eventually propose new ones, more adequate to their specific classroom realities. Furthermore, higher education institutions should seek to ensure that both students and teachers are '[...] aware of the opportunities of a multicultural classroom environment' (Xerri 2016, 29). Unfortunately, multicultural training is not generally regarded as a priority in teacher preparation (Cushner 2008).

Only recently, internationalisation of higher education has become a topic of institutional and political relevance in Portugal. Our findings suggest that its effects, especially in regard to the diversity resulting from the increased enrolments of international students, did not seem to constitute a main institutional concern. Certainly, Portugal does not have the 'first-mover advantage' (Urbanovič, Wilkins, and Huisman 2016, 494) as countries like Australia, the UK, or the US do. In other words, being a 'catch-up' country in terms of international education can constitute a handicap for Portugal in the global competition for international students. However, we argue that Portuguese higher education can also attain significant advantages from this country's peripheral status in the international market of higher education. Since most institutional strategies directed to diversity issues are yet to be developed, Portuguese higher institutions can reform their structures without making the same mistakes that other well-established countries have already made. Drawing on an extensive body of research from different countries and regions in the world, Portuguese universities can anchor their future practices in evidence-based recommendations, developing institutional strategies capable of surpassing the wide-spread idea according to which international students carry numerous 'deficits' (Jones 2017).

Indeed, even though it is crucial for universities to recognise that culturally diversified students have diverse (learning) needs and requirements, institutions should avoid approaching international students through a deficit lens. By doing that, they will end up engaging in paternalistic practices, reducing international students to fragile entities who are in constant need of support. As observed by one of the students: you don't always want people to single you out and make it clear that they are nice and helping. Moreover, institutionally addressing international students through a deficit lens clearly places the root of the problem in their own (cultural) inadequacies, without admitting the existence of potential problems within higher education institutions. In fact, if international students were to be welcomed in a truly multicultural university, perhaps they would not even experience additional struggles when compared to their local peers. By adopting a deficit view of international students, all institutional strategies directed to them will unavoidably be rooted in the assumption that international students are the ones who need to adapt to the host university, excluding the need for universities to also adapt to their students. Through this perspective, higher education institutions will not be able to adequately support international students in their learning quests, let alone '[...] create a sustainable multicultural and multilingual environment' (Singh 2012, 276) for the whole academic community.

As argued above, multiculturalism cannot end in the integration of diversity within an existing system, but needs to promote systemic change in order to be able to successfully accommodate 
diversity. According to Parekh (2002), "we" cannot integrate "them" so long as "we" remain "we"; "we" must be loosened up to create a new common space in which "they" can be accommodated and become part of a newly reconstituted "we"' (204). This is precisely what Portuguese universities, and any university for that matter, should take into account when developing policies and strategies focused on diversity issues. Internationalisation policies, goals and measures also need to be made available and clearly explained to all higher education stakeholders in order to ensure successful institutional changes. The analysis of the 12 narratives presented here suggests that Portuguese higher education institutions have been slow in acknowledging their increasingly diverse student bodies. Most certainly, they have a long journey ahead in terms of internationalisation strategies, diversity issues, and international student support. The recommendations made in this article provide a useful empirical starting point for the efficient development of multicultural policies and practices in higher education institutions from Portugal and, potentially, from other similar 'catch-up' countries.

In spite of its contributions to the ongoing debate on multiculturalism and cultural diversity in higher education contexts, this research does not come without limitations. Even though it provides a means to understand how cultural diversity is being dealt with in some Portuguese higher education institutions, a full assessment of institutional policy and practices cannot be rooted solely in international students' perceptions. The rich narrative data presented above can constitute a starting point for continuing research on cultural diversity and HE internationalisation in non-English-speaking countries. Further research would benefit from incorporating the perspectives of other relevant higher education stakeholders such as administrators, academic and non-academic staff, local students, to obtain a more complex overview of the actual policies and practices currently in place.

\section{Note}

1. According to data provided by the Portuguese National Directorate of Statistics regarding Education and Science.

\section{Disclosure statement}

No potential conflict of interest was reported by the authors.

\section{Funding}

This research was supported by the Portuguese Foundation for Science and Technology (FCT) and by the European Social Fund, under the Human Capital Operational Programme (POCH) from Portugal 2020 Programme [grant number SFRH/ BD/90745/2012]; and by the Portuguese Government, through the FCT, under the CIIE's strategic funding [grant number UID/CED/00167/2013].

\section{ORCID}

Cosmin I. Nada (D) http://orcid.org/0000-0001-5780-1763

Helena C. Araújo (D) http://orcid.org/0000-0003-2988-3209

\section{References}

Altbach, Philip G. 2004. "Globalisation and the University: Myths and Realities in an Unequal World." Tertiary Education and Management 10 (1): 3-25. doi:10.1080/13583883.2004.9967114.

Arasaratnam, Lily A. 2013. "A Review of Articles on Multiculturalism in 35 Years of IJIR." International Journal of Intercultural Relations, Multiculturalism, Beyond Ethnocultural Diversity and Contestations 37 (6): 676-85. doi:10.1016/j.ijintrel.2013. 09.006.

Asmar, Christine. 2005. "Internationalising Students: Reassessing Diasporic and Local Student Difference." Studies in Higher Education 30 (3): 291-309. doi:10.1080/03075070500095713.

Avery, Helen. 2016. "At the Bridging Point: Tutoring Newly Arrived Students in Sweden." International Journal of Inclusive Education 21 (4): 1-12. 
Barnett, George A., Moosung Lee, Ke Jiang, and Han Woo Park. 2016. "The Flow of International Students from a Macro Perspective: A Network Analysis." Compare: A Journal of Comparative and International Education 46 (4): 533-59.

Beine, Michel, Romain Noël, and Lionel Ragot. 2014. "Determinants of the International Mobility of Students." Economics of Education Review 41: 40-54. doi:10.1016/j.econedurev.2014.03.003.

Biggs, John, and Catherine Tang. 2007. Teaching for Quality Learning at University: What the Student Does. Buckingham: Open University Press.

Bolaffi, Guido. 2003. Dictionary of Race, Ethnicity and Culture. London: Sage.

Brown, Lorraine, and lain Graham. 2009. "The Discovery of the Self through the Academic Sojourn." Existential Analysis 20 (1): 79-94.

Bryman, Alan. 2012. Social Research Methods. New York: Oxford University Press.

Callahan, Rebecca M. 2005. "Tracking and High School English Learners: Limiting Opportunity to Learn." American Educational Research Journal 42 (2): 305-28.

Carroll, Judith, and Janette Ryan. 2007. Teaching International Students: Improving Learning for All. Abingdon: Routledge.

Caruana, Viv. 2014. "Re-thinking Global Citizenship in Higher Education: From Cosmopolitanism and International Mobility to Cosmopolitanisation, Resilience and Resilient Thinking." Higher Education Quarterly 68 (1): 85-104.

Caruana, Viv, and Josef Ploner. 2010. Internationalisation and Equality and Diversity in Higher Education: Merging Identities. http://eprints.leedsbeckett.ac.uk/600/.

Casa-Nova, Maria José. 2013. “Direitos Humanos: Da Sua Possibilidade Teórica à Sua (Im) Possibilidade Prática Numa Era de Naturalização Das Desigualdades." Revista Portuguesa de Educação 26 (2): 139-57.

Castles, Stephen. 1997. "Multicultural Citizenship: A Response to the Dilemma of Globalisation and National Identity?" Journal of Intercultural Studies 18 (1): 5-22.

Castles, Stephen. 2010. "Understanding Global Migration: A Social Transformation Perspective." Journal of Ethnic and Migration Studies 36 (10): 1565-86.

Cortesão, Luíza. 1998. O Arco-Íris Na Sala de Aula : Processos de Organização de Turmas: Reflexões Críticas. Lisboa: Instituto de Inovação Educacional.

Cui, Dan, and Jennifer Kelly. 2013. "Too Asian?' Or the Invisible Citizen on the Other Side of the Nation?" Journal of International Migration and Integration 14 (1): 157-74.

Cushner, Kenneth. 2008. "International Socialization of Young People: Obstacles and Opportunities." International Journal of Intercultural Relations 32 (2): 164-73.

Deca, Ligia, Eva Egron-Polak, and Cristina Ramona Fiț. 2015. "Internationalisation of Higher Education in Romanian National and Institutional Contexts." In Higher Education Reforms in Romania, edited by Adrian Curaj, Ligia Deca, Eva Egron-Polak, and Jamil Salmi, 127-147. Cham: Springer.

Duff, Patricia A., and Jill Sinclair Bell. 2002. "Narrative Research in TESOL: Narrative Inquiry: More than Just Telling Stories." TESOL Quarterly 36 (2): 207-213.

Dunne, Ciarán. 2013. "Exploring Motivations for Intercultural Contact among Host Country University Students: An Irish Case Study." International Journal of Intercultural Relations 37 (5): 567-78.

Erichsen, Elizabeth Anne. 2011. "Learning for Change: Transforming International Experience as Identity Work." Journal of Transformative Education 9 (2): 109-33. doi:10.1177/1541344611428227.

Etherington, Kim. 2004. Becoming a Reflexive Researcher: Using Our Selves in Research. London: Jessica Kingsley.

European University Association. 2013. Internationalisation in European Higher Education: European Policies, Institutional Strategies and EUA Support. Brussels: European University Association.

Ferdman, Bernardo M. 2017. "Paradoxes of Inclusion: Understanding and Managing the Tensions of Diversity and Multiculturalism." The Journal of Applied Behavioral Science 53 (2): 235-63.

Glazer, Nathan. 1998. We are All Multiculturalists Now. Cambridge: Harvard University Press.

Guo, Yan, and Shibao Guo. 2017. "Internationalization of Canadian Higher Education: Discrepancies between Policies and International Student Experiences." Studies in Higher Education 42 (5): 851-68.

Heng, Tang T. 2017. "Voices of Chinese International Students in USA Colleges: 'I Want to Tell Them That ... '." Studies in Higher Education 42 (5): 833-50.

Horta, Hugo. 2010. "The Role of the State in the Internationalization of Universities in Catching-up Countries: An Analysis of the Portuguese Higher Education System." Higher Education Policy 23 (1): 63-81.

Hughes, Hilary, and Christine S. Bruce. 2013. "International Students' Experiences of Informed Learning: A Pedagogical Case Study." International Journal of Pedagogies and Learning 8 (2): 106-19. doi:10.5172/ijpl.2013. 8.2.106.

Inglis, Christine. 1996. Multiculturalism: New Policy Responses to Diversity, Policy Paper No. 4. Management of Social Transformations Programme (MOST). Paris: UNESCO.

Jones, Elspeth. 2017. "Problematising and Reimagining the Notion of 'International Student Experience'." Studies in Higher Education 42 (5): 933-43.

Koerber, Amy, and Lonie McMichael. 2008. "Qualitative Sampling Methods a Primer for Technical Communicators." Journal of Business and Technical Communication 22 (4): 454-73.

Larson, Colleen L. 1997. "Re-presenting the Subject: Problems in Personal Narrative Inquiry." International Journal of Qualitative Studies in Education 10 (4): 455-70. 
Lee, Jenny J., and Charles Rice. 2007. "Welcome to America? International Student Perceptions of Discrimination." Higher Education 53 (3): 381-409. doi:10.1007/s10734-005-4508-3.

Levey, Geoffrey Brahm. 2012. "Interculturalism vs. Multiculturalism: A Distinction without a Difference?" Journal of Intercultural Studies 33 (2): 217-24. doi:10.1080/07256868.2012.649529.

Lillyman, Sue, and Clare Bennett. 2014. "Providing a Positive Learning Experience for International Students Studying at UK Universities: A Literature Review." Journal of Research in International Education 13 (1): 63-75. doi:10.1177/ 1475240914529859.

Méango, Romuald. 2014. International Student Migration: A Partial Identification Analysis, SSRN Scholarly Paper ID 2392732. Rochester, NY: Social Science Research Network. https://papers.ssrn.com/abstract=2392732.

Montgomery, Catherine, and Liz McDowell. 2009. "Social Networks and the International Student Experience: An International Community of Practice?" Journal of Studies in International Education 13 (4): 455-66. doi:10.1177/ 1028315308321994.

Nada, Cosmin I., and Helena C. Araújo. 2017. "The Multicultural Experience of International Students in Portugal: A Narrative Approach." Journal for Multicultural Education 11 (3): 176-88. doi:10.1108/JME-09-2016-0049.

Nada, Cosmin I., Catherine Montgomery, and Helena C. Araújo. 2018. "You Went to Europe and Returned Different: Transformative Learning Experiences of International Students in Portugal." European Educational Research Journal. doi:10.1177/1474904118765334.

Nye, Malory. 2007. The Challenges of Multiculturalism. http://www.tandfonline.com/doi/abs/10.1080/ 14755610701458915.

Otten, Matthias. 2003. "Intercultural Learning and Diversity in Higher Education." Journal of Studies in International Education 7 (1): 12-26. doi:10.1177/1028315302250177.

Papastergiadis, Nikos. 2000. The Turbulence of Migration: Globalization, Deterritorialization, and Hybridity. Cambridge: Polity Press.

Parekh, Bhikhu. 2002. Rethinking Multiculturalism: Cultural Diversity and Political Theory. Hampshire: Macmillan.

Ploner, Josef. 2015. "Resilience, Moorings and International Student Mobilities - Exploring Biographical Narratives of Social Science Students in the UK." Mobilities: 1-20. doi:10.1080/17450101.2015.1087761.

Rienties, Bart, Simon Beausaert, Therese Grohnert, Susan Niemantsverdriet, and Piet Kommers. 2012. "Understanding Academic Performance of International Students: The Role of Ethnicity, Academic and Social Integration." Higher Education 63 (6): 685-700.

Riessman, Catherine Kohler. 2005. "Narrative Analysis." In Narrative, Memory and Everyday Life, edited by Nancy Kelly, Christine Horrocks, Kate Milnes, Brian Roberts, and David Robinson, 1-7. Huddersfield: University of Huddersfield.

Rooduijn, Matthijs. 2015. "The Rise of the Populist Radical Right in Western Europe." European View 14 (1): 3-11.

Rumbley, Laura E., Philip G. Altbach, and Liz Reisberg. 2012. "Internationalization within the Higher Education Context." In The Sage Handbook of International Higher Education, edited by Darla K. Deardorff, Hans de Wit, and John D. Heyl, 3-26. Thousand Oaks, CA: Sage.

Saleh, Muna, Jinny Menon, and D. Jean Clandinin. 2014. "Autobiographical Narrative Inquiry: Tellings and Retellings." LEARNing Landscapes 7 (2): 271-82.

Shaw, Jenny. 2009. "The Diversity Paradox: Does Student Diversity Enhance or Challenge Excellence?" Journal of Further and Higher Education 33 (4): 321-31. doi:10.1080/03098770903266018.

Singh, Manjet Kaur Mehar. 2012. "Friendship Patterns between International and Local Undergraduates in a Malaysian Public Institution of Higher Learning." International Journal of Social Sciences and Education 2 (1): 267-80.

Spector-Mersel, Gabriela. 2010. "Narrative Research: Time for a Paradigm." Narrative Inquiry 20 (1): 204-24.

Stoer, Stephen, and Luíza Cortesão. 1999. Levantando a pedra: da pedagogia inter-multicultural às políticas educativas numa época de transnacionalização. Biblioteca das ciências do homem 12. Porto: Afrontamento.

Tiryakian, Edward A. 2003. "Assessing Multiculturalism Theoretically: E Pluribus Unum, Sic et Non." International Journal on Multicultural Societies 5 (1): 20-39.

Toyokawa, Teru, and Noriko Toyokawa. 2002. "Extracurricular Activities and the Adjustment of Asian International Students: A Study of Japanese Students." International Journal of Intercultural Relations 26 (4): 363-79. doi:10.1016/ S0147-1767(02)00010-X.

Trahar, Sheila. 2008. "It Starts with Once upon a Time ...." Compare: A Journal of Comparative and International Education 38 (3): 259-66.

Urbanovič, Jolanta, Stephen Wilkins, and Jeroen Huisman. 2016. "Issues and Challenges for Small Countries in Attracting and Hosting International Students: The Case of Lithuania." Studies in Higher Education 41 (3): 491-507.

Volet, Simone E., and Grace Ang. 2012. "Culturally Mixed Groups on International Campuses: An Opportunity for Intercultural Learning." Higher Education Research \& Development 31 (1): 21-37. doi:10.1080/07294360.2012.642838.

Walter, Jennifer S. 2018. "Global Perspectives: Making the Shift from Multiculturalism to Culturally Responsive Teaching." General Music Today 31 (2): 24-28.

Xerri, Daniel. 2016. "Teaching and Learning English in a Multicultural Classroom: Strategies and Opportunities." Journal for Multicultural Education 10 (1): 19-32.

Yuen, Jenny K. S. 2008. "The Moon in Foreign Countries Is Particularly Round and Bright' - Narratives of Chinese Immigrant Women in the UK." Compare: A Journal of Comparative and International Education 38 (3): $295-306$. 